\title{
CHALLENGES OF HIGHER EDUCATIONAL DOCUMENTARY INSTITUTIONS IN SUPPORTING MERDEKA BELAJAR KAMPUS MERDEKA PROGRAM
}

\author{
Ciwuk Musiana Yudhawasthi* \& Lydia Christiani** \\ *Universitas Bhayangkara Jakarta \\ **Universitas Diponegoro \\ Email: inadhani@gmail.com, lydia.christiani@live.undip.ac.id
}

DOI: $10.24252 /$ kah.v9cf2

\begin{abstract}
ABSTRAK: Independent Learning Independent Campus (MBKM) merupakan sebuah program yang diluncurkan Kementerian Pendidikan, Kebudayaan dan Ristek untuk mendukung kesiapan peserta didik menghadapi tantangan dalam dunia kerja dengan mengaplikasikan active learning. Lembaga dokumenter di lingkungan perguruan tinggi, yaitu perpustakaan, arsip dan museum seyogyanya dapat menjadi mitra strategis dalam mendukung program MBKM. Karena lembaga dokumenter tersebut memiliki semua syarat yang diperlukan, baik sarana maupun prasarana guna mencapai keberhasilan program MBKM. Penelitian ini dilakukan untuk mengetahui bagaimana kesiapan lembaga dokumenter di lingkungan perguruan tinggi dalam memanfaatkan peluang tersebut dan apa saja tantangan dan kendala yang dihadapinya. Dengan menggunakan metode kualitatif melalui metode pengumpulan data wawancara mendalam dan studi pustaka, peneliti mendapat simpulan bahwa tantangan terbesar yang dihadapi lembaga dokumenter adalah regulasi serta kesiapan SDM. Untuk itu perubahan regulasi dan kurikulum pendidikan serta pengenalan ilmu murni dokumentasi baru, merupakan prioritas dalam perbaikan penyelenggara pendidikan profesi bidang ilmu perpustakaan, kearsipan dan museologi.
\end{abstract}

Kata kunci: perpustakaan, arsip, musium, dokumentasi, pembelajaran aktif

ABSTRACT: Independent Learning Independent Campus (MBKM) was launched by the Ministry of Education, Culture, and Research and Technology to support the readiness of students to face challenges in the world of work by applying active learning. Documentary institutions in universities, namely libraries, archives, and museums, should become strategic partners in supporting the MBKM program because the documentary institution has all the necessary conditions, facilities, and infrastructure to succeed MBKM program. This study aimed to determine the readiness of documentary institutions in the university environment to exploit the opportunities and challenges and what obstacles they encountered. This study used the qualitative method and in-depth interviews for data collection and a literature study. The researcher concludes that the biggest challenges facing documentary institutions are regulation and the readiness of human resources. Due to this, changes to regulations and educational curricula and the introduction of new documentation of pure science are priorities in improving professional education providers in library science, archives, and museology.

Keywords: Library; archive; museum; documentation; active learning

\section{INTRODUCTION}

Universities are currently required to design and implement innovative learning processes to achieve optimal learning outcomes and have skills that are always relevant to the demands and 
dynamics of workplaces. It applies to all aspects of learning outcomes, ranging from attitudes, knowledge, and skills (Pujiriyanto, n.d.). The new program, called Merdeka Belajar Kampus Merdeka (MBKM) or Independent Learning Independent Campus is expected to be the answer to these demands as the MBKM learning concept provides students with the broadest possible challenges and opportunities for the development of creativity, capacity, personality, and needs. Moreover, it provides opportunities to develop independence in seeking and finding knowledge through realities and field dynamics, such as ability requirements, real problems, social interaction, collaboration, self-management, performance demands, targets, and achievements (Siregar et. al., 2020).

Through the MBKM program, students are free to take credits outside of their study program for three semesters, consisting of one semester taking courses outside of their study program and the other two semesters carrying out learning activities outside their university (Direktorat Jenderal Pendidikan Tinggi Kementerian Pendidikan dan Kebudayaan, 2020). Students can carry out various learning activities outside tertiary institutions and outside of their study program, as stated in the Regulation of the Minister of Education and Culture No. 3 of 2020 Article 15 paragraph 1 . One of them is by carrying out internships/work practices in the industry or other workplaces. Moreover, it can also perform community service projects in villages, teach in education units, participate in student exchanges, conduct research or entrepreneurial activities, create independent studies/projects, and participate in humanitarian programs. All these activities must be under the supervision of lecturers. The MBKM program is expected to provide field contextual experiences, thus improving student competencies, being ready to work, or even creating new jobs. MBKM is a form of autonomous and flexible learning to create a learning culture that is innovative, unfettered, and in line with student needs (Universitas Pendidikan Indonesia, n.d.).

MBKM implements the concept of student-based learning or active learning, which is in line with the Government Regulation Number 57 of 2021 concerning National Education Standards Article 12 (1) which states that learning is implemented in an interactive, inspiring, fun, challenging, and motivating learning atmosphere for students to participate actively. Tutors must provide sufficient space for initiative, creativity, independence following students' talents, interests, and physical and psychological development. The learning implementation is performed by providing examples, assistance, and facilities. Thus, all components involved in teaching in schools need to pay attention to this to create a conducive environment for learning. The implication is that teachers must have sufficient competence to be active learning facilitators, primarily through Project-Based Learning, Discovery Learning, and Problem-Based Learning. Active learning is any teaching approach in which all students are requested to be involved in the learning process (Bonwell \& Eison, 1991).

Active learning is the opposite of "traditional" methods of instruction, where students are passive recipients of knowledge from an expert. In contrast, active learning can take various forms and be implemented in any discipline. Problem-based active learning engages students with resources and activities by requiring them to do something and collaborate. Students do not just sit and listen or watch. They are encouraged to engage in small or large activities centered on writing, speaking, problem-solving, or reflection. This active learning is the core and the realization of the MBKM vision, which is eventually followed by the preparation of various MBKM activity programs that all students from various campuses can follow throughout Indonesia.

One of the MBKM activities is the Teaching Campus program. In this program, students can assist in socializing the Ministry of Education and Culture, Research and Technology learning products, including emergency curriculum, learning modules, $A K S I$, learning house portals, and others. Important to note that students can also socialize and improvise promotional materials for Pancasila (Indonesia state philosophy) student profiles and become ambassadors for behavior change education during the pandemic. Besides the Campus Teaching program which has the main objective of helping to improve the quality and equity of basic education, MBKM also offers nine other activities, namely the Indonesian International Student Mobility Award 
which facilitates Indonesian students to study in 10 of the world's best universities for one semester; Independent Study GERILYA (Solar Power Initiative Movement) which calls 50 exact science students from universities in Indonesia to join in honing skills and developing practical competencies in the field of clean energy, primarily Solar Photovoltaic (PV); Internships in various government and private institutions to enrich work experience; Building villages (Thematic Community Service Program) as well as Humanitarian Projects to contribute ideas for solutions to social issues; An independent student exchange that facilitates students to study across campuses and across cultures throughout Indonesia to explore and learn about the cultural diversity of the archipelago; Research or Research that seeks students to be involved in research projects in research center laboratories with research professionals; Independent Studies that provide opportunities for students to master various applied sciences across majors from experts in their fields; as well as the Entrepreneurship program which aims to help students to develop their businesses under professional guidance. Learning in the Merdeka Kampus provides challenges and opportunities for the development of creativity, capacity, personality, and student needs, as well as developing independence in seeking and finding knowledge through realities and field dynamics such as ability requirements, real problems, social interaction, collaboration, self-management, performance demands, targets, and achievements (Ministry of Education and Culture, Research and Technology, 2021). Experiential learning programs with flexible pathways within the scope of MBKM are expected to facilitate students to develop their potential according to their passions and talents.

\section{PREVIOUS FINDINGS}

\section{Documentary Institutions in Higher Education as MBKM Partners}

Media and learning resources available on campus are galleries, libraries, museums, archives, and sites within the university environment often referred to as GLAMS. If we refer to the new concept of documentation, as stated by Niels Windfeld Lund - Professor of the School of Documentation Studies at Tromso University Norway - all objects managed by galleries, libraries, archives, museums, and sites are documents. Lund even asserted, there is no physical form of the document unless humans make it printed. Documents do not have to be in permanent physical form (Sudarsono, 2016). Lund's statement explains documents in a digital situation and clearly explains objects of collection that are intangible, such as speech and gestures. Thus, the oral tradition in the repertoire of Batik, the Pencak Silat movement, the process of making the Keris and its meaning, and the stories of Panji are all documents. This concept is very different from the conventional document concept that was previously understood. The new meaning of this document helps explain the interconnectedness of galleries, libraries, museums, archives, and sites. In the book "Towards a New Era of Documentation", it is stated that institutions that have or carry out document management tasks in any format are referred to as documentary institutions (Sudarsono, 2016).

Essentially, GLAMS in the campus environment is an organization whose mission is to implement the Tri Dharma (three pillars) of Higher Education, taken from Sanskrit. "Tri" means three, and "Dharma" means an obligation. Tri Dharma of Higher Education is a principle held by every public and private university in Indonesia. It is as stated in Law No. 12 Article 1 Paragraph 9. The entire academic community is obliged and responsible for realizing the Tri Dharma. According to the law, the academic community itself is a community that has a scientific tradition by developing an academic culture. The academic community referred to here is lecturers and students. They must carry out the pillars. Education is a conscious and planned effort to create a learning atmosphere and learning process. Students actively develop their potential to have religious-spiritual strength, self-control, personality, intelligence, noble character, and skills needed by themselves, society, nation, and state. Meanwhile, research is systematically carried out according to scientific principles and methods to obtain information, data, and information related to understanding and testing a branch of science and technology. Meanwhile, community service is an activity of the academic community that utilizes science and technology to advance the community's welfare and educate the nation's life. 
The implementation of Tri Dharma certainly cannot run smoothly without documentary institutions such as libraries, archival institutions, and museums. The library is a familiar institution in the campus environment, with the power of library-based references in a broad sense. The library provides a variety of references from various sciences. The use of libraries has no doubt played a strategic role in helping to provide referral assistance. With the number of university libraries in Indonesia, students should have affluent learning resources. The nonlibrary materials in the form of archives, manuscripts, photos, and video documentaries are generally stored in university campus archive canters, such as the collections of the University of Indonesia Archives Center and the University of Surabaya Archives Center. No less attractive are campuses that have art faculties or focus on the arts and have galleries; for example, the R.J. Katamsi Gallery is an art gallery owned by the Indonesian Art Institute (ISI) Yogyakarta. As for museums, from the report of the Indonesian Higher Education Museum Network (JMPTI), currently, there are 46 museums located in several universities in Indonesia with various collection subjects, such as medicine, science, ethnography, biology, history, education, law, as well as art. Some examples of university museums are the Anatomy Museum of FKIK Unika Atma Jaya Jakarta, the Insect Museum of the Bogor Agricultural Institute, and the Museum Loka Budaya Cenderawasih University, Papua. Meanwhile, several universities are recorded as managing cultural heritage sites, such as the Kimpulan Temple by the Indonesian Islamic University in Yogyakarta and the Mount Penanggungan Site by the University of Surabaya.

Observing the description above, it is very natural that GLAMS in the campus environment becomes a strategic partner for implementing the MBKM program. With various facilities owned (libraries, galleries, museums, and cultural heritage sites), universities provide students access to developing and utilizing existing campus facilities as media and learning resources in implementing MBKM activities. Thus, students also contribute to developing the potential of GLAMS through internship programs, start-ups, student exchanges, and Campus Teaching. For example, to design an active learning program, students who will become learning facilitators in the era of hybrid learning need to master learning strategies and make maximum use of learning resources on campus. Although the number is still limited, this shows how extraordinary the GLAMS assets in the university environment can be used as the center of the Big Data for Indonesian Higher Education GLAMS and can be optimized as media and learning resources for Merdeka Campus. However, GLAMS optimization process needs to start from the core of the problems faced by most of the GLAMS in Indonesia.

\section{Formulation of the Problem}

Percival and Ellington (1993) stated that in conventional learning models, of the many available learning resources, it turns out that only textbooks are used as learning resources. Meanwhile, various other learning resources, in general, have not been used optimally. Conditions in Indonesia are relatively not much different. The use of teaching materials and textbooks in learning is very dominant compared to other learning resources, such as libraries, laboratories, field studies, slides, the internet, computers, and others (Supriyadi, 2015). However, during the Covid-19 pandemic, the conditions have slightly changed, especially the use of computers in learning shows an increase. It means that the service aspect of GLAMS in the campus environment needs more attention and improvement. Hybrid learning conditions create a need for up-to-date, comprehensive, and interactive digital learning resources accessible online and offline. As a partner, GLAMS in the campus environment can undoubtedly be used by the academic community and the wider community. Therefore, GLAMS needs to be prepared to immediately revitalize the institution to establish itself as a strategic part of the Independent Curriculum (Kurikulum Merdeka), especially as a partner for MBKM in responding to challenges loaded with the digital world.

There are currently 2,694 universities in Indonesia, public and private, and it is the third country with the most campuses after India and China (Arifin \& Muslim, 2020). This condition is fascinating because the significant number of universities needs to be accompanied by the awareness of networking and collaboration between institutions, including documentary institutions in the university environment. The urgency of networking and collaborating is 
recognized as an inseparable part of the digital era, which needs to be the fulcrum of universities' libraries, archival institutions, and museums. It is to realize convergent documentation services in the digital era to strengthen their existence as academic community partners in teaching, research, and community service, known as the Tri Dharma of Higher Education.

From some of the studies above, this research focuses on studying the condition of libraries, archives, and museums in universities in Indonesia, especially in their readiness to become strategic partners of the MBKM program. Specifically, this study provides a brief overview of the challenges and problems faced by managers of libraries, archives, and museums in universities in supporting the MBKM program.

\section{RESEARCH METHODOLOGY}

This research was a qualitative study that explored phenomena with individuals or groups as research subjects with data collected from the original environment, without the researcher's intervention, and analyzed using the researcher's interpretation (Creswell \& Creswell, 2018). This study explored phenomena of documentary institutions' networks in the realm of higher education, including networks of libraries, archival institutions, and museums, primarily related to the readiness of human resources at documentary institutions in the university environment in supporting the MBKM program. This research used qualitative data, based on the characteristics of this study, in the form of perceptions, understandings, and personal experiences of the managers of library networks, archival institutions, and museums in the higher education environment in encouraging the readiness of human resources in documentary institutions in the higher education environment to support the success of the MBKM program.

Research data were obtained through a semi-structured interview process toward research informants selected using the snowball sampling technique. The first informant was determined through the purposive sampling technique. Research data were processed and analyzed using matrix analysis (Miles and Huberman, 1992). Data analysis was carried out by compiling data collected by grouping data by category, breaking it down into units, synthesizing data, compiling data based on patterns, sorting data to be studied, and making conclusions so that researchers and others could understand them (Hardani et al., 2020).

\section{RESULTS AND FINDINGS ANALYSIS}

\section{Role of Leaders of Libraries, Archives, and Museums in Higher Education}

As an institution built to facilitate learning activities, a library, archive, and museum face various problems and obstacles in a university environment. Concerning Law Number 12 about Higher Education, in the Elucidation of Article 41 Paragraph 1, learning resources, facilities, and infrastructure in higher education, archival institutions are not listed as educational facilities such as libraries and museums. Thus, the existence of university campus archival institutions is minimal in higher education internals compared to libraries and museums. It is not surprising that students, teaching staff, and stakeholders in higher education are not familiar enough with the function of archival institutions as learning resources. As a result, students and teaching staff rarely use this institution for teaching, research, and community service purposes. However, it does not mean that there are no archival institutions in the university environment at all.

In Indonesia, university libraries are currently incorporated in the Indonesian Higher Education Library Forum (FPPTI). The organization, established in 2005, has 1,006 members spread over 25 regions of Indonesia. Furthermore, archival institutions in higher education are incorporated in the Indonesian Higher Education Archives Association (PAPTI), founded in 2017 and now consists of 15 State Universities (PTN) as active members. Meanwhile, in 2019, the Indonesian Higher Education Museum Network (JMPTI) was initiated, with 46 public and private university museums members. In general, the legal basis to support the university's tri dharma is the main obstacle. 
Interviews with the Secretary-General of PAPTI, Sandi Ruswandi, S.T., M.M, and the Coordinator of JMPTI, Dr. Erlina Wiyanarti, M.Pd, reveal that in principle, the presence of archival institutions and museums is to support the tri dharma of higher education. Even Erlina Wiyanarti emphasized that in the campus museum, academic and non-academic communities can see evidence of the achievements of teaching, research, and community service from a university. Through a well-planned exhibition, the public is provided with information. The transfer of knowledge and the inculcation of values can be internalized from an early age (Gmeet, 27 July 2021 at $21.00-22.00$ and 28 July 2021 at $16.00-17.00$ ).

For example, the Anatomy Museum FKIK Atma Jaya Unika has an open house program synergized with the Student Executive Board of Medical Faculty (BEM-FK) throughout Indonesia. During these activities, the museum, laboratories, and libraries will open tours to promote campus facilities. Prospective students get information about learning facilities on campus and enlightenment about studying medicine at FKIK Atma Jaya Unika (Yudhawasthi 2020). The same thing also applies at the Taruna Abdul Djalil Museum, Army Military Academy Magelang. There is a tradition that every cadet who will learn at the Magelang Military Academy (Akmil) during orientation will first be invited to tour the museum to get "spiritual food". In the hope that after getting to know the best Akmil seniors and graduates enshrined in the museum, they will be inspired and excited to learn and excel for their country (interview with the Governor of the Military Academy Major General TNI Eka Wiharsa, 20 August 2018). Besides being used during the orientation period, the museum is also subsequently used as a learning facility, as stated by the Anatomy Museum founder, Atma Jaya Unika FKIK, Dr. Liliana Sugiharto MS, PA(K). Students can use museums to review material received after lectures are over, just like a library. The museum provides a hands-on experience as it provides various specimens that students can see, touch, smell, and even hold directly, especially on anatomical preparations for medical students (interview, 2 May 2017).

What about other types of museums in Indonesian universities? University museums in Indonesia are currently categorized into humanities and social sciences museums, natural history museums, science and technology museums, archive collection museums and memorial halls, and art museums (Komunitas Jelajah, 2021). Some university museums even specialize in the history of their journey and have solid archival collections, such as the University of Surabaya Library, Archives and Museum. The three documentary institutions are under one management. Still, the three of them are also trying to converge knowledge, which becomes the university's collective memory and disseminating knowledge in the University of Surabaya (Ubaya) faculties. The three documentary institutions are under one management. However, all three are trying to converge science, which becomes the university's collective memory and disseminate knowledge to the faculties at the University of Surabaya (Ubaya). Even though admitting that the management is not perfect yet, Amirul Ulum, M.PI, Director of Ubaya Libraries, Archives, and Museums, emphasized that the merging of Ubaya libraries, archives, and museums into one directorate is one step to provide excellent service to all Ubaya academics, especially in supporting the MKMB program.

Although the library has more legal basis as a learning facility in a university environment, in reality, the condition of the library in a university environment is not more appropriate than that of a museum or archival institution. Not all libraries can provide excellent service, especially during this pandemic. The Chairperson of FPPTI, Mariyah, M. Hum., states that the library's various conditions depend on the support from each university leadership and how librarians can convince the leadership of the importance of the library's role in supporting learning, research, and even community service. As the University of Indonesia Central Library manager, Mariyah explained that the UI Central Library is trying to automate routine library services to anticipate remote services during the pandemic and is also ready to accept various educational backgrounds of students for internships in the library. Students of the Department of Library Science, the Department of Language, and even the Faculty of Engineering will assist with the library program, especially during the pandemic. Mariyah admitted, this internship program will be adapted to the needs of the library, such as the knowledge management service program, 
which generally conducts research searches with specific subjects (interview 27 July 2021, 16.00-17.00). Mariyah's statement is in line with what is conducted at the Ubaya Library. One of the activities that can benefit interns is a series of librarianship courses as various disciplines are needed to develop information retrieval learning materials for various subjects of knowledge, such as architecture, science and technology, and many more. Similarly, Amirul stated the importance of leadership support for library development. For Ubaya itself, the support from the Foundation and the Rectorate is excellent; the various proposed and accountable developments are generally very well supported by the leadership (interview 28 July 2021, 09.00-10.00)

Representing higher education archival institutions, the Secretary-General of PAPTI, Sandi Ruswandi, S.T., M.M. stated that PAPTI was created in addition to increasing the existence of archival institutions, but also to improve the skills of its members to convince leaders of the role and function of archival institutions in supporting the Tri Dharma of higher education. Higher education archive institutions will optimally facilitate the academic community through skilled managers who have extensive networks. Good performance will undoubtedly increase the leadership's confidence in the institution's performance (interview 28 July 2021, 16.00-17.00).

The statements of research informants further emphasize the need for legal support for documentary institutions in the university environment. The legal umbrella for organizing libraries and museums in universities is clearly stated in Law Number 12 of 2012 concerning Higher Education. The Elucidation of Article 41 Paragraph 1 concerning learning resources, facilities, and infrastructure in higher education explicitly mentions libraries and museums as learning resources that need to be established in universities. However, only a few museums have been provided with a UPT level, such as libraries. In Indonesia, museums in universities are to managing by faculties, departments, or study programs (Jejaring Museum Perguruan Tinggi Indonesia, 2021). Whereas archival institutions are still only seen as internal campus administrative data centers. Their function is not yet widely understood as a learning resource, so they are still underutilized for teaching, research, and community service. The Department of Communication, History, Architecture, and Civil Engineering, for example, often requires archives as a source of learning. This includes medical records that hospitals process within the scope of university management. This problem is certainly understandable, as is stated in the explanation of Article 41, paragraph 1 of Law Number 12 of 2012; archival institutions are not mentioned as one of the sources, facilities, and educational infrastructures like other documentary institutions, namely libraries and museums. Conditions in implementing documentary institutions at universities such as libraries, archives, and museum institutions, especially as learning sources, cannot be separated from organizational management. Organizing or in groups requires leaders who can manage and improve the talent capabilities possessed by the people he leads. The leader is responsible for showing direction and replacing the navigator, spokesperson, and coach. Therefore, a leader needs to have a leadership style that can affect his followers. Leadership issues emerged along with the beginning of human history, namely since humans realized the importance of living in groups to achieve common goals. They need people who have advantages over others, regardless of what form of a human group. There is no denying that humans always have limitations and certain advantages. Survey results from 'The Economics' on "15 Best CEOs (Head of Executive Organization) in 2021 in Indonesia according to Employees" revealed that leadership characteristics that are proven to ensure the organization's existence, among others, are a concern for subordinates. This characteristic ranked second most important after the vision of the leader. It means that human organizational management is the key to improving organizational performance and readiness to deal with changes. Robbins (1996) formulated leadership as the activity to influence people's behavior towards specific goals. In other words, leadership is the ability to influence the group to achieve group goals.

As a decision-maker, the leader must be the spearhead to project development and develop the necessary resources. Therefore, a leader must have a proactive attitude. A leader 
must decide to which parts of the organization they will distribute the source of funds. This funding source includes money, time, supplies, labor, and reputation. A leader must also negotiate at every level, both with subordinates, superiors, and outsiders (Luthans, 1992). The organization that succeeds in achieving its objectives and can fulfill its social responsibility will depend on its leaders. If leaders can carry out their functions properly, the organization may be able to achieve its target.

\section{Human Resources Capability of Libraries, Archival Institutions, and Museums in Higher Education}

A good organization grows and develops with an emphasis on human resources to optimally carry out its functions, especially in dealing with the dynamics of environmental changes. Thus the technical, theoretical, conceptual, moral skills of organizational actors at all levels (levels) of work are needed. Moreover, the position of human resources at the highest position helps encourage organizations to display behavioral norms, values, and beliefs as an essential means to improve their performance. Many Human Resources (HR) functions are changing and closely linked to the vision, strategy, structure, and processes of an organization's systems. However, HR professionals must develop and demonstrate new competencies to fulfill their roles and responsibilities for the continuous transformation of HR functions. HR functions change to achieve higher value in their organizations. Many HR functions show reducing HR costs, improving the quality of HR services, promoting stronger relationships with needs, and improving performance (Yeung et al., 1996).

Employee performance generally refers to achievements that are measured based on standards or criteria set by the organization. To achieve high human resource performance, the management intends to improve the organization as a whole. Performance is a very complex concept, both in terms of definition and measurement. Skill control by the leader emphasizes developing individual skills and abilities (Challagalla \& Shervani, 1996, p. 90). In the context of skill control, employees are trained by encouraging, supporting, and enhancing behavior, for example, training, internships aimed at improving skills and abilities, such as presentation, negotiation, interpersonal communication, planning, and other relevant skills (Challagalla \& Shervani 1996, p. 90). Education is the key to improving HR performance. It means that the work world is very dependent on the results of education in all units, including, of course, higher education which produces workers in the fields of libraries, archives, and museums. Educational outcomes are inseparable from how the education unit builds the curriculum to optimize students.

It is undeniable that the ability of human resources is the most critical factor in the management of documentary institutions in the university environment. Among the three documentary institutions in the campus environment, the university museum occupies a unique position because the scientific background of the managers is all experts in their respective fields of science, and most of them have doctoral degrees in their field. For example, the Frank Williams Museum of Bird Sculpture at Udayana University is led by an ornithologist. While the Insect Museum Prof. Soemartono Sosromarsono Department of Plant Protection, Bogor Agricultural University is led by an entomologist. Museums within the Faculty of Medicine, such as the FKUI Museum, Anatomy Museum FKIK Unika Atma Jaya, Anatomy Museum Universitas Brawijaya, are led by doctoral degrees. The Ethnographic Museum of Airlangga University is led by an anthropologist who also holds a doctorate (Jejaring Museum Perguruan Tinggi Indonesia, 2021).

Considering this condition, museums in universities have a very close relationship with learning activities, research, and even community service in their respective fields. Erlina Wiyanarti, the JMPTI Coordinator, emphasized that the museum is a means for universities to carry out community service. Through museums, the public has access to knowledge and scientific developments at no cost. The campus should not be an ivory tower, with secure access that only the academic community can visit. The campus can become a water tower through its museum, which is open to anyone who wants to study or even take a break (interview 10 
January 2019). The curator of the Museum Loka Budaya of the University of Cendrawasih Jayapura Papua, Enrico Yuri Kondologit, M.Sc., also expressed a similar statement that the campus museum is not only a reference center for Papuan traditions for researchers and students, but the campus museum has even become a Papuan tourist destination for foreign tourists. With more than 2,800 Papuan ethnographic collections neatly arranged in a not-toolarge building, this museum is ready to welcome visits, even outside working hours. The Museum Loka Budaya is one of the university museums established during the early development of higher education in Indonesia in the 1970s. However, the oldest university museum in Indonesia is the Biology Museum, Faculty of Biology, Gadjah Mada University (UGM) Yogjakarta, founded in 1964.

Most museum managers' improvement of museum management skills is carried out by attending courses organized by the Ministry of Education and Culture or sharing sessions with museum experts, both at home and abroad, held internally or by other parties, such as museum associations and communities. The standardization of museums proclaimed through PP 66 of 2015 concerning Museums forced network managers to learn from each other and exchange information regarding standardized museum management. This is not much different from what was done by FPPTI and PAPTI. Although all managers are graduates of the Department of Library and Archives Science, internal and external short courses are often conducted to make managers more skilled and meet the standard requirements. Unfortunately, there is very little museology education in Indonesia, unlike the more existent Department of Library and Archives Sciences. There are only two SKKNI related to the field of work of museums, namely guides and curators.

Meanwhile, in museums, according to PP 66 of 2015, the field that is close to service is educators who, undoubtedly, are not just tour guides. Besides, similar to cataloging in libraries and registering in archives, museums require technical personnel to carry out registration and inventory. As with libraries and archives, museums also always need preservation personnel to maintain physical collections. In museums, exhibitors or museographers require expertise in exhibition details. Such demands do not apply in libraries and archival institutions.

An expert in public relations is one more skill that is expected to be in the museum, which libraries and archival institutions very much need. Public relations is performing external communication from the institution to the community and managing internal communication within the organization. Barriers to organizational communication significantly influence the "face" of the organization, which will be related to the organization's performance. The staff who work in public relations own the spirit of public relations, and all managers of documentary institutions must also own it. All the personnel is the "face" of the organization, meaning that communicating is essential for every individual who works at the campus documentary institution. Although it is acknowledged that managing documentary institutions in the campus environment are not very encouraging, a network and organizational collaboration can target improving the skills of managers, even during a pandemic.

FPPTI Chair Mariyah, M. Hum., JMPTI Coordinator Dr. Erlina Wiyanarti, M.Pd. and Secretary-General of PAPTI Sandi Ruswandi, S.T., M.M., agreed that through courses, sharing sessions in online meetings followed by evaluations, the personal capacity building did not experience any problems. It is just that the learning outcomes return to the seriousness of each individual in learning. Sudarsono (2018) explains the Four Pillars of Support and the Five Main Powers very interestingly, and that a person who chooses the profession as a librarian must possess them. In the researcher's opinion, what Sudarsono (2018) conveys is very relevant concerning other documentary institutions. Sudarsono explained that librarianship is a calling for life, a spirit of life, service, and professional work regarding the Four Pillars of Support. It is evident that in this case, living as a documentalist must have idealism and feel that the profession is a calling for life so that it will always be a spirit of life and realize that one performs a work of service. It means that as a documentalist, one must be ready to do the best service 
work and innovate and create to meet the needs of one's audience. Service work and professionalism will be challenging to fulfill without a spirit as a calling for life and a spirit of life.

Furthermore, how documentalists can improve their abilities, Sudarsono explained in the concept of the Five Main Powers, namely that documentary professionals must be able to think critically, analytically, and critically. These abilities are closely related to reading and writing skills. A documentalist has to be bright and has to be able to present an entrepreneurial spirit so that they can support themselves well and create growth opportunities. The best service works can be created here so that documentary institutions can also compete and exist as reliable (rich) service providers. What is no less critical above all is that a documentalist must uphold ethics (right), act, and work appropriately by the rules, norms, and ethics that apply wherever they are.

How to create human resources that can become complete and happy human beings and benefit others? The answer goes back to how professional documentary education is supported and developed according to the needs of the times. Based on quipper campus data, at least 30 private and public universities have study programs based on Library Science and Archival Sciences with levels ranging from Diploma, Strata 1 (S1) to Strata 2 (S2). This department uniquely belongs to various faculties, including the humanities, cultural sciences, administrative sciences, social and political sciences, computer sciences, and communication sciences. An even more unique condition occurs in museum science, or what is more familiarly called Museology. Until now, no single university in Indonesia has a department or study program that specifically teaches the basics of managing the museum world. Museology is only limited to specialization at the Strata 1 or Strata 2 formal education level. Museology is even just one course in some universities, generally under the auspices of a study program based on History and Archeology.

Based on the Higher Education Database (PDDIKTI) accessed on 30 August 2021, there were 43 listings for library science-based education, eight records for archiving science-based education, and 0 for museum-based education or museology (Ministry of Education and Culture, Research and Technology, 2021). However, if further investigated in each listing related to the active status of library science-based education providers, only 37 library science-based education providers had active status. Meanwhile, five library science-based education providers have the status of transformation (joined with other sciences). Meanwhile, one provider of library science-based education, namely the Islamic Library and Information Science study program at Antasari State Islamic University Banjarmasin, is closed. The condition of archival science-based education is also not entirely active. Only six of the eight archival sciencebased education providers' listings are active, while the other two are closed. Apart from including archival science-based education implementation data at PDDIKTI, 3 study programs are still not integrated into PDDIKTI, namely D4 Records and Archives Management at the University of Indonesia, D4 Records Management at the Open University, and D4 Records and Archives Management at Gadjah Mada University. In addition, there are providers of archival science-based education that are still at the level of specialization, such as the D4 Archive Specialization at the Information and Public Relations Study Program at Diponegoro University.

The current list of education providers cannot accommodate the level of specialization in the PDDIKTI database because the search system is compiled based on the study program, not at the level of specialization or the course level. This is also why the implementation of museum science-based education or museology cannot be found in the PDDIKTI listing since the implementation of museology education is still limited to the level of subjects in history and archaeology. Based on data from the History Education Study Program in Indonesia (P3SI), currently, the implementation of museum-based education is still limited to subjects taught in the History study program, located at the Indonesian Education University, University of Indonesia, Lampung State University, Lambung Mangkurat University, University of Indonesia. Surabaya State University, Muhammadiyah Mataram University, Tanjung Pura University, Galuh Ciamis University, Bangun Nusantara Veterans University, Sultan Ageng Tirtayasa University, Jember University, and STKIP PGRI Bandar Lampung. Moreover, there is also an Introduction to Museology course taught under the Archaeological Studies program at Jambi University. 
Meanwhile, at the level of specialization in Museology, there were only two education providers, namely the University of Indonesia and the University of Gadjah Mada, both held under the Archeology study program.

Table 1. Recapitulation of the Number of Education Providers in the Field of Documentation (Library Science, Archival Sciences, and Museology) with Active Status

\begin{tabular}{clcccc}
\hline No. & \multicolumn{1}{c}{ Field of Study } & Amount & \multicolumn{2}{c}{ Level } \\
& & & Study Program & Specialization & Subject \\
\hline 1 & Library Science & 37 & 37 & - & - \\
2 & Archival Science & 11 & 9 & 2 & - \\
3 & Museology & 15 & - & 2 & 13 \\
Source: Researcher Data Process (2021) & & &
\end{tabular}

Referring to the concept of documents as objects managed by libraries, archives, and museums, the field of science that is more appropriate for this field is Documentation Science. Accommodating Documentation Science as a pure science in a study program with a document basis as its field of studies such as library science, archival science, and museum science needs to be done immediately since the results of education are inseparable from how the curriculum is built by the education unit to optimize students' ability to understand a field of science. Documentation Science needs to be introduced as a general introductory course that must be comprehended by students who want to become professionals in the field of documentation, such as libraries, archives, and museums (documentalists). Of course, Documentation Science was introduced, which had undergone further development after the neo-documentalist movement, or developments commonly known as the New Documentation Science (Ilmu Dokumentasi Baru - IDB).

Curriculum can be broadly defined as the learner's experience. This definition is adopted by almost all formal schools, even outside of school. It starts from John Dewey's definition of experience and education as stated by Caswell and Campbell since 1930 (Hyman, 1973 in Kristiawan et. al., 2019) that the curriculum is all the experiences that students gain while under the supervision of educators. Brady and Kenedy (2007) in Kristiawan et. al. (2019) stated that the curriculum includes students' continuous experiences while in an educational institution. According to Kristiawan, the meaning of curriculum is a set of student experiences that contain learning objectives, teaching materials, learning strategies, and learning evaluations. The curriculum is also a reflection of what people feel, think, believe, and do. The curriculum is also what the older generation chooses for, the younger generation whose contents can be history, politics, ethnicity, culture, gender, phenomena, aesthetics, ethics, divinity, and international. The curriculum makes generations try to find their identity. As a written plan for learning activities, the curriculum is defined as the interaction between four systems: teaching, learning, instructing, and the curriculum system. In this system, there is a combination of the personality system and the social system. The curriculum system consists of individuals whose behavior is contained in the curriculum. (Kristiawan et. al., 2019).

What about the curriculum in educational institutions that produce librarians, archivists, and museum experts? Society is not static. Along with the advancement of science and technology, society is constantly changing, moving towards increasingly complex developments. In this increasingly complex social life, various group forces also emerge that may pressure the implementation and practice of education, including pressures in developing curriculum content as a tool and guideline for the implementation of education. Meaningful education is education that focuses on outcomes that are usually expressed in several different levels. The most important of all in the curriculum is content because the content includes what material will be 
taught. It cannot be separated from the philosophy and educational theory in determining learning materials or teaching materials. It is challenging to determine learning materials that depart from only one particular philosophy in its implementation. So in practice, it tends to be used eclectic and flexible (Kristiawan et. al., 2019).

As Zais (1976) stated in Kristiawan et. al. (2019), significance is one of the criteria used in determining content, namely what part of a field of science needs to be included or emphasized. For example, basic concepts and principles in each discipline need to be prioritized due to the implications of content on the curriculum can include three main things, namely science, process, and values. In this case, the development of new documentation science needs to be a concern in developing curriculum content. If the choice of material is determined not to refer to the educational goals or instructional goals to be achieved by the curriculum; as a result, students will not get optimal knowledge and experience according to the times' development. Educational institutions for library science, archival science, and museum science need to consider the basic concepts and theories of the underlying scientific discipline, namely the New Documentation Science (IDB).

\section{DISCUSSION}

The New Documentation Science (IDB) makes documents the center of its study so that fields such as library science, archival science, and museum science need to use IDB as the basis. In classical times, documents were seen as text-based evidence. Still, with technological changes, documents are seen as a word processor through machines but the concept changes in line with the association of the document's relationship with teaching, evidence, social systems, communication, technology, jurisprudence, representation, and more. Currently, experts enriched the meaning of documents by various traditions, and documents are no longer just texts. The characteristics of documents extracted from Docam - an association that focuses on researching various discourses related to documents - state five aspects that make an object can be called a document, namely indexicality, plurality, fixity, documentality, and productivity.

Indexicality, the document is a representation of something else or points to something else. In the philosophical tradition of Charles Sanders Peirce (1839-1914), this idea is referred to as indexicality (think how "index finger" and "pointer finger" mean the same thing). Briet makes the connection between documents and indexicality in defining documents as "indexical symbols or signs" (The Document Academy, n.d.). Ron Day's writings on documents and indexicality refer to a situation.

Document plurality has information (mental), material (physical), and communication (social) aspects. The mental component includes the individual, cognitive aspects of the document; material components include technological and physical aspects of documents; and the social component covers the document's economic, political, and cultural aspects. By complementing each other, we can recognize that something more than the "content" of the document contributes to its meaning (The Document Academy, n.d.). Niels W. Lundemphasises that, in analyzing a document, one can look at its information, materials, or communications (The Document Academy, n.d.). Gorichanaz and Latham's team in Docam proposes an analytical framework for considering document plurality. The four types of information that appear in a plurality of documents are intrinsic (part of the material), extrinsic (external information, such as metadata), adtrinsic (personal associations that a person has with the object), and abstrinsic (the current feelings and emotions that a person has when experiencing the object).

Fixity (certainty), in its physical form, the document is relatively stable (Gorichanaz and Latham 2016, 1114-1133). For example, a book from the 1500s may, for the most part, be the same as when it was printed. Documents are inherently fixed, but moveable is their strength, as Bruno Latour points out who created the immutable mobile concept. In the view of John Seely Brown and Paul Duguid, the document's determination also enabled him to build social groups because "a sense of community arises from reading the same text". David Levy has shown that documents, especially on the web, are not entirely fixed (The Document Academy, n.d.). 
Documentality, this term describes the extraordinary power of documents. Documents perform specific social functions, such as holding a wedding or uniting a company under a brand identity. Bernd Frohmann (The Document Academy, n.d.) divides documentality into four aspects: functionality, historicity, social complexity, and autonomous agency. Functionality refers to how a document performs a particular social function, such as holding a wedding or uniting a company under a brand identity. Historicity concerns the location of documents at a particular time and place, such as scientific publications that have been made for centuries. Social complexity refers to the understanding that documents require training, teaching, and learning to be created and done. Whereas Autonomous Agency means that the document affects us emotionally (for example, someone might be "moved" by the book), and the document also limits and allows specific actions on our part (for example, a No Parking sign). Independently, Maurizio Ferraris also discussed documentality. For Ferraris, documents are social objects, namely social actions that are expressed in material form (Ferraris, 2013).

Productivity, from existing documents, new documents can be created. Briet referred to it as a primary document and a secondary document. An example of a deer in a zoo can be considered a primary document considering the countless secondary documents it produces. Sabine Roux builds on this idea by rejecting any notion of hierarchy that primary and secondary names might imply, preferring to think of documents as "rhizomes", based on the philosophical work of Deleuze and Guattari (The Document Academy, n.d.). Lars Björk also considers document productivity, but from a slightly different angle. Björk examines problems that arise from attempting to reproduce documents, such as in photocopying or digitizing (The Document Academy, n.d.).

If one pays attention, all types of material collected in documentary institutions have these five aspects. For example, S. Sudjojono's painting entitled Battle of Sultan Agung and Jan Pieterzoon Coen is a museum collection. Painting is indexical; its presence represents the artist's ideas, ideas, and thoughts that may be influenced by social life and economics, politics, and so on. S. Sudjojono'spainting as a document has a stable and transportable character. The painting painted in 1973-1974has not changed even though it was restored in 2008. The size of this painting is $3 \times 10 \mathrm{~m}$ and is a remarkable historical episode, considering the extraordinary mobilization of the people of Central Java and Batavia. The painting has a solid social description of the function, history, social complexity, and autonomous agency. It is undeniable that these paintings can become new documents, such as books, photos, films, and more.

The new understanding of documents and documentation carried by the New Documentation Science as the foundation of justification for the convergence vision of documentary institutions such as libraries, archival institutions, and museums needs to be further disseminated to the managers of documentary institutions, especially to institutional leaders, including documentary institutions located in higher education institutions. This understanding may start from the point of view of the Documentation Universe proposed by Blasius Sudarsono (2016) as follows: 


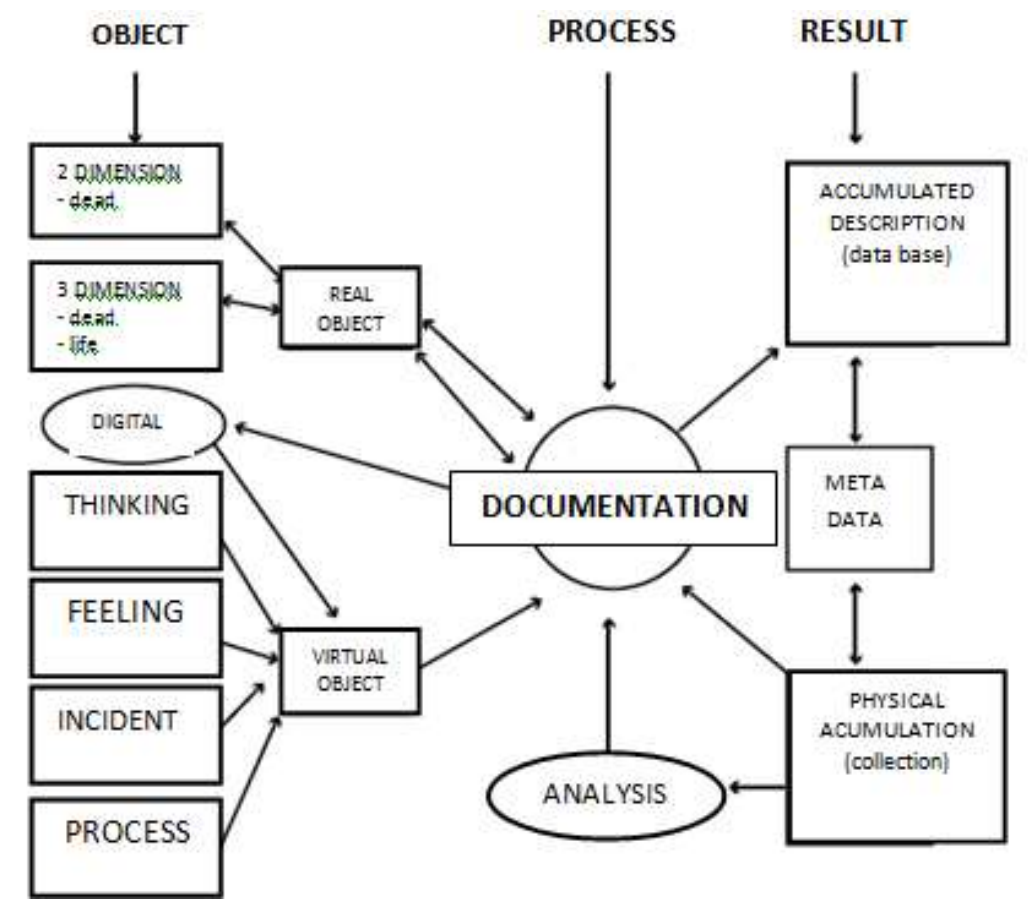

Figure 1. The Documentation Universe Source: Sudarsono (2016)

Blasius Sudarsono emphasized that documentation is basically a cyclical process. Virtual objects or real objects are documented into real objects or digital objects. With the help of information and communication technology, these objects can be re-documented into new virtual objects, and the process can be repeated frequently. Besides, Blasius Sudarsono also suggests that documentation is a step in creating knowledge and/ or science. Documentation is also seen as an activity that makes explicit, tacit knowledge and manages explicit knowledge. Documentation is a simulation of the work of the brain. Documentation is a function that everyone has to do. This understanding will eventually lead to the point of view that documentation is an object, process, and science (Sudarsono, 2016).

Furthermore, Blasius Sudarsono emphasized that four pillars can be used as the foundation of the architecture of documentation building in Indonesia, namely Law no. 6 of 1956; Presidential Regulation Number 20 of 1961 (also known as UURPS 20 of 1961); The initial concept of documentation put forward by Paul Otlet; and the New Documentation Movement (neo-documentalist) in the early 2000s. The four pillars can be the fulcrum to build new comprehension and meaning of the new documentation. The new era of documentation is the turning point and the primary key to understanding and carrying out activities at a convergent documentary institution. The concept of convergence of various documentary institutions, which is currently still co-existent, can only be realized based on the New Documentation Science (IDB), which places documents as the focus of the study object (Sudarsono, 2016).

This vital point also needs to be considered by the managers of documentary institutions in universities and the leadership of higher education institutions. To answer the challenges of libraries, archives, and museums in the university environment in supporting the MBKM program, teaching New Documentation Science needs to be an integrated part of the higher education curriculum, especially for study programs that make documents the focus of the study object. This is carried out to strengthen the scientific identity of library science, archival science, and museum science and produce more competent human resources as documentalists in documentary institutions in any form (libraries, archival institutions, and museums). Thus, 
documentary institutions are ready to answer the challenges of the new era of libraries, archives, and museums as convergent documentary institutions, including documentary institutions in universities.

\section{CONCLUSION}

Based on the results of the research analysis, the following conclusions are obtained:

1. MBKM is a program that supports students to improve thinking and social skills through an active learning approach. In applying active learning, documentary institutions in higher education must be able to strengthen their existence as MBKM partners to support the vision and mission of higher education;

2. As a partner of MBKM, documentary institutions in higher education have various challenges. The main challenges are the legal basis and leadership support in the management of documentary institutions as well as the capacity of human resources based on the Basic Framework for Indonesian Librarianship which includes four pillars of support, five main strengths, and three main targets as a bright, rich and right person;

3. To realize bright, rich, and right documentary human resources require education that can mold bright, rich, and right human resources for documentary institutions. The success of education in molding bright, rich, and right human resources for documentary institutions is very dependent on the curriculum design. Therefore, the curriculum for the documentary profession needs to pay attention to changes, including changes due to the development of information and communication technology as well as changes in people's lifestyles. It includes the changes in the world of documentation itself explicitly, especially after the neodocumentalist movement that deconstructed the formulation of documentation, which was initially only limited to library documentation, to become more conceptual by focusing on the function of the document and no longer on the level of document format.

4. The new conception of the documentation world embodied in the New Documentation Science needs to be immediately accommodated by study programs that make documents as objects of study, such as library science study programs, archival sciences, and museum sciences so that the human resources produced by these study programs are more well equipped for accomplishing the convergence of libraries, archival institutions, and museums in the Higher Education environment. This, in turn, will be able to confirm the existence of libraries, archival institutions, and museums in the university environment as MBKM partners to support the university's vision and mission optimally;

5. In addition to improving the curriculum for education providers in the field of documentation, it is also necessary to immediately mend the regulations and optimize the profession in the field of sustainable documentation;

6. The MBKM program is an opportunity for libraries, archival institutions, and museums in universities to show their existence as MBKM partners to optimally support the vision and mission of higher education as a means of active learning in the campus environment.

\section{Recommendations}

Based on the research results, recommendations are proposed for documentary institutions in universities in Indonesia to welcome the challenges in supporting the MBKM program as follows:

1. Policymakers in universities need to sit together and try to formulate the role of museums and archives in higher education as learning facilities that are as important as libraries. A legal umbrella regarding the existence of museums and archival institutions in universities will make it easier for managers to realize their mission in supporting the tri dharma of higher education. Museums and Archives of Universities have an equally important role and function in providing learning facilitation for the entire academic community and the general public. 
2. Capacity building of human resources is essential in all sectors. Educational institutions capable of producing professions in libraries, archives, and museums need to make curriculum changes by considering current changes and developments in terms of technology, community needs, and lifestyle. If the paradigm of museums, in general, has developed from object-oriented to subject-oriented, libraries and archives seem to have to go to the service work as well. It means that human resources in all documentary institutions are required to increase innovation and creativity to support the campus vision and mission;

3. The science of new documentation is a basis in developing the science of documentary institutions. Therefore, new documentation science should be introduced as the philosophy of the documentary profession. As a pure science from the sciences that make documents their main study, new documentation science should also be taught to various other sciences since documenting activities are corporate and individual work. Moreover, every profession has a responsibility to make documentation.

\section{REFERENCES}

Arifin, S. \& Muslim, M. (2020). "Tantangan Implementasi Kebijakan Merdeka Belajar, Kampus Merdeka pada Perguruan Tinggi Islam Swasta di Indonesia". Al Ilmi Jurnal Pendidikan Islam Vol 3 No 1 https://core.ac.uk/download/pdf/328159881.pdf

Bonwell, C. \& Eison, J. (1991). "Active Learning Creating Excitement in the Classroom". ASHEERIC Higher Education Report, Washington DC School of Education and Human Development, George Washington University. https://files.eric.ed.gov/fulltext/ED336049.pdf

Challagalla, G., Shervani, T. (1996). "Dimensions and Types of Supervisory Control: Effects on Salesperson Performance and Satisfaction”. Journal of Marketing. Vol. 60 (1), 89-105. https://doi.org/10.1177/002224299606000108

Creswell, J. \& Creswell, J. (2018). Research and Design Qualitative, Quantitative and Mixed Methods Approaches. Thousand Oaks: SAGE Publications Ltd.

Direktorat Jenderal Pendidikan Tinggi Kementerian Pendidikan dan Kebudayaan. (2020). Buku Panduan Merdeka Belajar- Kampus Merdeka. Jakarta: Direktorat Jenderal Pendidikan Tinggi Kementerian Pendidikan dan Kebudayaan. http://dikti.kemdikbud.go.id/wp-content/uploads/2020/04/Buku-PanduanMerdeka-Belajar-Kampus-Merdeka-2020

Ferraris, Maurizio. 2013. Documentality: Why it is Necessary to Leave Traces. Translated by Richard Davies. United States: Fordham University Press.

Gorichanaz, T. \& Latham, K. F. (2016). Document phenomenology: A framework for holistic analysis. Journal of Documentation, 72(6), 1114-1133.

Hardani, H. A., Ustiawaty, J., Istiqomah, R. R., Fardani, R. A., Sykmana, D. J., \& Auliya, N. H. (2020). Buku Metode Penelitian Kualitatif \&Kuantitatif . Edited by H. Abadi. Yogyakarta: CV. Pustaka Ilmu.

Indonesia. House of Representatives.Peraturan Pemerintah Republik Indonesia Nomor 66 Tahun 2015 tentang Museum.

Indonesia. House of Representatives. PeraturanPemerintahRepublik Indonesia Nomor 57 Tahun 2021 tentang Standar Nasional Pendidikan.

Indonesia. House of Representatives.Undang-UndangRepublik Indonesia Nomor 12 Tahun 2012 tentang Pendidikan Tinggi.

Indonesia. Ministry of Education and Culture. Peraturan Menteri Pendidikan dan KebudayaanNomor 3 Tahun 2020 tentang Standar Nasional Pernidikan Tinggi. 
Kementerian Pendidikan, Kebudayaan, Riset, dan Teknologi RI. Pangkalan Data Pendidikan Tinggi. Retrieved August 30, 2021 from https://kampusmerdeka.kemdikbud.go.id/program

Kementerian Pendidikan, Kebudayaan, Riset, dan Teknologi RI. Program Kampus Merdeka. Retrieved August 25, 2021 from https://forlap.kemdikbud.go.id/prodi

Kristiawan, M., Yuniarsih, Y., Fitria, H. \& Refika, N. (2019). Supervisi Pendidikan. Bandung: Alfabeta

Jejaring Museum Perguruan Tinggi Indonesia. Laporan Universeum 22-23 Mei 2021.

Komunitas Jelajah. Laporan Indonesia Museum Awards 2020.

Luthans, F. (1992). Organizational Behavior. New York: McGraw-Hill,.

Miles, M. B. \& Huberman, A. M. (1992). Analisis Data Kualitatif: Buku Sumber tentang Metode-Metode Baru. Translated by Tjetjep Rohendi Rohidi \& Mulyarto. Jakarta: Universitas Indonesia.

Robbins, S. P. (1996). Organizational Behavior: Concepts, Controversies, Applications. New Jersey: Prentice Hall.

Percival, F. \& Ellington, H. (1993). A Handbook of Educational Technology. London: Kogan Page.

Pujiriyanto. (n.d.). "Meretas Sistem Pembelajaran Paradigma Baru" . Retrieved June 30, 2021 from https://media.neliti.com/media/publications/222224-meretas-sistempembelajaran-paradigma-ba.pdf

Siregar, N., Sahirah, R. \& Harahap, A. A. (2020). "Konsep Kampus Merdeka Belajar di Era RevolusiIndustri 4.0". Fitrah: Journal of Islamic Education, Vol 1 (1) https://jurnal.staisumatera-medan.ac.id/index.php/fitrah/article/view/13/9

Sudarsono, B. (2016). Menuju Era Baru Dokumentasi. Jakarta: LIPI Press.

Sudarsono, B. (2018). Cerita tentang Pustakawan dan Kepustakawanan. Jakarta: Perpustakaan Nasional Republik Indonesia.

Supriyadi. 2015. "Pemanfaatan Sumber Belajar dalam Proses Pembelajaran”. Lantanida Journal, Vol. 3 (2).

The Document Academy. (n.d.). "What is Document?". Retrieved July 31, 2021 from http://documentacademy.org/?what-is-a-document

Universitas Pendidikan Indonesia. (n.d.). Sosialisasi Panduan Merdeka Belajar Kampus Merdeka. Bandung: Universitas Pendidikan Indonesia. http://cs.upi.edu/v2/assets/docs/Materi Sosialisasi MBKM UPI.pdf

Yeung, A., Woolcock, P. \& Sullivan, J. (1996). Identifying and Developing Competencies for the Future. Human Resource Planning, 19(4), 48-58.

Yudhawasthi, C. M. (2019, October 8). Perkembangan Museum Universitas di Indonesia Menuju Kancah Global [Paper Presentation]. The National Seminar on Innovative Steps for the University Museum to Support the Competitiveness of the Nation in the Era of the Industrial Revolution 4.0, Jakarta, Museum Bank Indonesia, Indonesia

Yudhawasthi, C. M. (2019, April 10-11). Dinamika Museum Universitas [Paper Presentation]. The National Colloquium Strategic Position and the Role of University Museums in the Implementation of the Tridharma of Higher Education, Jakarta, FKIK Unika Atma Jaya, Indonesia. 